Analysis

\title{
Influences of transaction costs in environmental policy
}

\author{
Anthea Coggan $^{\mathrm{a}, *}$, Stuart M. Whitten ${ }^{\mathrm{b}, 1}$, Jeff Bennett ${ }^{\mathrm{c}, 2}$ \\ a CSIRO Sustainable Ecosystems, 306 Carmody Rd., St. Lucia, Qld, 4067, Australia \\ b CSIRO Sustainable Ecosystems, Gungahlin Homestead, Bellenden St., Gungahlin, Canberra, Australia \\ c Crawford School of Economics and Government, Australian National University, Canberra, ACT 0200, Australia
}

\section{A R T I C L E I N F O}

\section{Article history:}

Received 4 December 2009

Received in revised form 14 April 2010

Accepted 18 April 2010

Available online 23 May 2010

\section{Keywords:}

Transaction costs

Environmental policy

Influences

\begin{abstract}
A B S T R A C T
There is a growing literature reporting the extent of transaction costs for environmental policies. However understanding why transaction costs occur and why they are small or large is also important for efficient policy selection and evaluation. Following an analysis of the organisational economics literature and reports of the extent of transaction costs for a number of environmental policies, three key influences to transaction costs in environmental policies are identified. These are the following: 1) the characteristics of the transaction for the environmental good; 2) the nature of the transactors; and 3) the current institutional environment and arrangements. These affect transaction costs to the government and all other parties influenced by a policy. Transaction costs occur due to actions of information collection and policy design, policy enactment and establishment, implementation and contracting, administration and monitoring, and enforcement. An interrogation of transaction cost influences reveals that: 1) the influence varies between parties and is affected by the actions and interactions of and between all parties to a policy; 2) how transaction costs are experienced varies across time; and 3) who experiences transaction costs depends on the policy itself. Future policy selection and refinement will benefit from empirical analysis of the causes of transaction costs.
\end{abstract}

Crown Copyright @ 2010 Published by Elsevier B.V. All rights reserved.

\section{Introduction}

Land use decisions by individual landholders respond to a variety of incentives (Wills, 1997). Markets are the most widely used mechanism for signalling incentives to individuals in western society. Land owners are rewarded for land uses that produce marketable outputs but not for the other socially valued products such as the maintenance or enhancement of public goods (for example, environmental quality). When the market fails to supply a good to the level that is socially desirable, market failure is said to have occurred. It is at this point that intervention by government or non-government organisations to ensure the supply of public goods may be justified (Murtough et al., 2002). Intervention can be through a number of alternative policy instrument types: market based (including public purchase such as a competitive tender or public facilitation of a private market such as a cap and trade scheme), regulatory, or a combination which also draws on partnerships and social networks (Buitelaar, 2007). Each individual or package of policy instruments

Abbreviations: AES, Agri-Environment Schemes; CSIRO, Commonwealth Scientific Industrial Research Organisation; OECD, Organisation for Economic Co-operation and Development.

* Corresponding author. Tel.: +61 73214 2671; fax: +61 732142308.

E-mail addresses: anthea.coggan@csiro.au (A. Coggan), stuart.whitten@csiro.au (S.M. Whitten), jeff.bennett@anu.edu.au (J. Bennett).

${ }^{1}$ Tel.: +61262421683.

2 Tel.: +61261250154. (hereon referred to as policies) provides a different level, mix and distribution of benefits and costs which occur over varying spatial and temporal scales.

A caveat on any form of intervention is that it must be efficient; that the benefits are greater than the costs. Critical to calculations of net benefit is the inclusion of the cost of the intervention and within this, the inclusion of the transaction costs; the cost of resources to define, establish, maintain and exchange property rights (McCann et al., 2005).

The literature defining transaction costs is extensive (e.g. Cheung, 1969; Williamson, 1973, 1981, 1998; Dahlman, 1979; Barzel, 1985; Stiglitz, 1986; North, 1990; Allen, 1991). There is also an extensive literature that sets out frameworks for measuring transaction costs broadly (Dahlman, 1979; Stiglitz, 1986) and for measuring the transaction costs of environmental policies explicitly (Colby, 1990; Howitt, 1994; Thompson, 1999) with the most comprehensive measurement framework provided by McCann et al. (2005). There is also a small but growing body of literature that report ex post measures of transaction costs of environmental policy (McCann and Easter, 2000; Howitt, 1994; Falconer et al., 2001; Falconer, 2000; Falconer and Saunders, 2002; Vatn et al., 2002; Rorstad et al., 2007; Kuperan et al., 2008; Mettepenningen et al., 2009).

What is missing in the current literature is an understanding and rigorous analysis of what influences transaction costs to all parties engaged in an environmental policy. That is, what influences transaction costs throughout environmental policy development, 
implementation and administration and what influences different types of transaction costs to be large or small and distributed across different parties. Without this information, policy decision makers may be limited in their ability to make informed ex ante decisions around policy selection, design and implementation frameworks for their problem context. Furthermore, efforts to refine the design of a policy for efficiency gains ex post are unguided (Falconer and Whitby, 1999; Falconer et al., 2001; McCann et al., 2005).

The objective of this paper is to address this gap in the literature for the influences of transaction costs. ${ }^{3}$ This is done through a review and synthesis of the current transaction cost literature. Two main sources of information are utilised. The first is organisational economics where transaction cost influences are discussed in the context of selecting a governance structure for production coordination. The second is a compilation of studies that have measured the transaction costs of various environmental policy instruments. By drawing this literature together, a further contribution of this paper is highlighting current knowledge gaps and areas for future research.

The paper is structured as follows. In Section 2 a background to the concept of transaction costs related to the supply of environmental goods, and how transaction costs occur in the creation and use of an environmental policy are provided. A discussion of measures of transaction costs of environmental policy highlighting the gaps in this current literature is also undertaken in Section 2. Section 3 contains the review of the current literature on what influences transaction costs. Section 3 also includes a discussion on how factors influence the transaction costs of both the public and private parties to the environmental policy. Section 3 concludes with a summary of influences of transaction costs for environmental policy. Conclusions, as well as discussion about further research, are provided in Section 4.

\section{Background}

\subsection{What are transaction costs?}

Transaction costs are the cost of resources used to define, establish, maintain and transfer property rights (McCann et al., 2005). In relation to the transfer of a product, transaction costs have been defined as all the costs that are not directly related to the production of that product (Lai, 1997; Nilsson and Sundqvist, 2007). Transaction costs arise because of information uncertainty and as a result of the actions that transactors must take to manage for this uncertainty. Transaction cost generating actions include searching for contract partners, gaining knowledge of materials and production, negotiating and concluding contracts and monitoring and enforcing contracts over time (Bromley, 1991; Kasper, 1998). Transaction costs typically occur as goods and services, travel costs, labour and time expended in a transaction. Matthews (1986) describes transaction costs as the costs of arranging a contract ex ante and monitoring and enforcing that contract ex post.

Institutions, the rules of behaviour which structure the economic, social and political behaviour of people, reduce uncertainty surrounding interactions and thereby reduce transaction costs (North, 1990). Institutions may be informal such as conventions, habits and social norms or formal and based on legal character such as contracts (North, 1990). Williamson (1998) describes these two levels of institution as the institutional environment and arrangements. The institutional environment is the legal, social and political rules that determine the context in which economic activity takes place while institutional arrangements are the governance structures which structure transactor interaction (markets, regulation and hierarchies)

\footnotetext{
${ }^{3}$ We note that understanding why transaction costs are distributed across different parties to a policy is also significant to policy design and refinement. This issue is touched on in this paper but is not addressed in detail.
}

(Williamson, 1990, 1998). Economists tend to take the institutional environment as given (Williamson, 1998). Property rights are a "subset of (formal) institutions for regulation of behaviour and social interactions with respect to objects of value" Challen (2000:15). Property rights reduce uncertainty and hence transaction costs in interactions between agents (Furubotn and Richter, 2000: 2-3). The definition and discussion of property rights vary across disciplines. Barzel (1997) refers to the economic and legal definitions of property rights. The former is a right which enables the right holder to enjoy a piece of property or to consume a good or services from an asset directly or indirectly through exchange. The latter is the protection of the former from the state which is essential for individuals to realise the economic benefits from assets (through enforcement). Others (Commons, 1968; Bromley, 1989, 1991; Schalger and Ostrom, 1992) note that the outcome of the property right allocation depends on the specifications or the rules and entitlements that are related to the use of the right. Schalger and Ostrom (1992) highlight that the benefit stream accruing to a right holder depends on the package of access, withdraw, management, exclusion and alienation rights held by authorised users, claimants, proprietors and owners of a good. The alienation component of the property right bundle enables complete right ownership and then owners of rights to benefit from actual exchange of the right consistent with property rights definitions such as that of Barzel. ${ }^{4}$

\subsection{Transaction costs and environmental goods}

Regardless of which rights are held in the 'bundle', the extent of the benefit stream associated with this bundle is affected by how clearly the rules, responsibilities and entitlements surrounding these rights are defined. For an authorised user with only access and withdraw rights, benefit is eroded if there are high costs of collecting information about when, where and how access and withdraw can take place. For a right owner, the benefits of exchange are eroded if there are high costs to define the good to be exchanged or there are high costs for buyers and sellers to find each other. For many environmental goods the bundles of rights surrounding management, access and exchange are either non-existent or not well defined, this is particularly the case surrounding the excludability component of the right. Goods for which rights and duties, particularly around excludability, are not well specified are considered to be some form of public goods. The undersupply of these and/or the fact that there are uncompensated costs for damage to these is discussed in terms of externalities.

A pure public good is a good that is both non-exclusive and nonrival (Ostrom and Ostrom, 1999). Non-exclusive means that the exclusion part of the right bundle is not well specified and therefore the costs incurred to prevent use by others far outweighs any gains from this action. Non-rival means that consumption benefits enjoyed by one person do not impinge on the benefits enjoyed by another and thereby do not impact on another's willingness or ability to consume (Weimer and Vining, 1992; Grafton et al., 2004). Non rivalry also occurs for production whereby the marginal cost of the provision of a good to an additional consumer is zero (Demsetz, 1970). Most public goods are not pure public goods, the OECD (2001) classifies pure and impure public goods into five categories depending on their degree of excludability and rivalry. Regardless of the purity of the public good, if it is too costly to exclude beneficiaries from the supply of a good it is also impossible to extract a charge for the provision of this good. As a result there are weak financial incentives for potential suppliers to provide the good above the level of private benefit. Poor definition of

\footnotetext{
${ }^{4}$ This is not suggesting that this is the only way that a right holder benefits from a bundle of rights. See Schalger and Ostrom (1992) for an in depth discussion of the implications for benefit of different bundles of rights.
} 
Table 1

Categories and types of transaction costs and how they are experienced in the creation and use of an environmental policy.

\begin{tabular}{|c|c|c|c|}
\hline \multirow[t]{2}{*}{ Activity category } & \multirow[t]{2}{*}{ Time period } & \multicolumn{2}{|l|}{ How are transaction costs experienced by } \\
\hline & & Policy administrator/public & Private parties \\
\hline \multirow[t]{3}{*}{$\begin{array}{l}\text { 1. Research, information } \\
\text { gathering and analysis } \\
\text { and policy design }\end{array}$} & $\begin{array}{l}\text { Prior to } \\
\text { implementation }\end{array}$ & $\begin{array}{l}\text { Time and resources associated with investigating the } \\
\text { problem and the benefits and costs of alternate solutions }\end{array}$ & $\begin{array}{l}\text { Time and resources of policy analysis (consultation, etc.) } \\
\text { and information collection to enable future compliance } \\
\text { and for lobbying }\end{array}$ \\
\hline & $\begin{array}{l}\text { Development and } \\
\text { implementation }\end{array}$ & $\begin{array}{l}\text { Time and resources associated with refining policy design } \\
\text { such as trials, public consultation, training, development of } \\
\text { procedures, investment in monitoring and auditing } \\
\text { infrastructure }\end{array}$ & $\begin{array}{l}\text { Time and opportunity cost of involvement in trials. Time } \\
\text { and resources invested in learning about the policy. } \\
\text { Investment in resources to enable monitoring } \\
\text { compliance }\end{array}$ \\
\hline & Ongoing & $\begin{array}{l}\text { Time and resources invested in policy review and } \\
\text { adjustment, information collection to support legal } \\
\text { proceedings, auditing, monitoring and enforcement }\end{array}$ & $\begin{array}{l}\text { Time and resources to find trading partners, research } \\
\text { contractual needs, understand policy amendments or } \\
\text { application in different circumstances, conduct } \\
\text { monitoring and support legal proceedings }\end{array}$ \\
\hline 2. Enactment & $\begin{array}{l}\text { Development and } \\
\text { implementation }\end{array}$ & $\begin{array}{l}\text { Time and resources invested in policy briefing and policy } \\
\text { change. Time and resources (staff, printing costs) of } \\
\text { preparing background documentation for legislation changes } \\
\text { (if required) }\end{array}$ & $\begin{array}{l}\text { Time and resources of lobbying the agencies either for or } \\
\text { against a new policy (meetings, materials). Opportunity } \\
\text { cost of waiting for legislation finalisation and clarity of } \\
\text { allowable actions }\end{array}$ \\
\hline 3. Establishment & $\begin{array}{l}\text { Development and } \\
\text { early implementation }\end{array}$ & $\begin{array}{l}\text { Time and resources in hiring and training staff, purchasing } \\
\text { equipment, advertising }\end{array}$ & $\begin{array}{l}\text { Time and resources of hiring and training staff and } \\
\text { purchasing equipment }\end{array}$ \\
\hline $\begin{array}{l}\text { 4. Implementation, } \\
\text { including contracting }\end{array}$ & $\begin{array}{l}\text { Implementation and } \\
\text { ongoing }\end{array}$ & $\begin{array}{l}\text { Time and resources invested in implementing policy, } \\
\text { allocating permits, brokering contracts, verifying contracts }\end{array}$ & Time and resources to negotiate and finalise contracts \\
\hline $\begin{array}{l}\text { 5. Support and } \\
\text { administration }\end{array}$ & Ongoing & $\begin{array}{l}\text { Time and resources invested in assessing applications, } \\
\text { auditing processes, keeping records, interpreting policy }\end{array}$ & $\begin{array}{l}\text { Time and resources invested in doing applications and } \\
\text { keeping records }\end{array}$ \\
\hline 6. Monitoring & Ongoing & $\begin{array}{l}\text { Time and resources invested in auditing compliance and } \\
\text { reporting on effectiveness }\end{array}$ & $\begin{array}{l}\text { Time and resources associated with activities to present } \\
\text { monitoring data and comply with monitoring process }\end{array}$ \\
\hline 7. Enforcement & Ongoing & $\begin{array}{l}\text { Opportunity cost of time to engage in enforcement. Cost of } \\
\text { litigation (if required) }\end{array}$ & Opportunity cost of time, fines and legal costs \\
\hline
\end{tabular}

Sources: Thompson, 1999; McCann and Easter, 1999; Falconer and Whitby, 1999; McCann et al., 2005; Buitelaar, 2007; Kuperan et al., 2008 ; Ofei Mensah, 2008.

the package and allocation of property rights also means that the transaction costs of signalling a positive or negative impact (externalities) from the supply or undersupply of a good are high. As a result these impacts are often uncompensated (Bromley, 1991; Challen, 2000).

When a good is supplied at a level considered to be less than socially optimal, government intervention may be justified. ${ }^{5}$ However, just as policy measures seek to reduce transaction costs in management or exchange of environmental goods, the development, implementation and administration of the policy also generates transaction costs to both the public policy maker and to the private parties affected by the policy (Whitten and Bennett, 2005). Government intervention is only justifiable on efficiency grounds when the benefits of the intervention are greater than the costs (including the transaction costs).

\subsection{Measures of environmental policy transaction costs}

The literature contains numerous categorisations and typologies of transaction costs in environmental policy. McCann et al. (2005) have developed a broad framework for categorising and measuring transaction costs. This framework follows Coase's (1960) recommendation that a typology of transaction costs should be broad enough to apply to market and non-market based policies and should be developed to include all phases of exchange to all parties. In McCann et al.'s framework, transaction costs are categorised into research and information collection and analysis, policy enactment (development of legislation), policy design and implementation, support and administration, contracting, compliance monitoring and detection and enforcement/prosecution. McCann et al. also highlight that policy transactors experience transaction costs at the baseline (before policy implementation), during development, early implementation, full implementation, and in an ongoing basis throughout the life of an established policy. McCann et al. highlight the importance of

\footnotetext{
5 This may be in the form of regulation or could be in the form of better assignment of rights to common property resources as per Ostrom (1990) and Wills (1997).
}

capturing transaction costs in all policy stages to generate a complete efficiency analysis. A summary of policy activities that generate transaction costs, who experiences them and when from McCann et al. (2005) and others is provided in Table 1.

Studies that measure the transaction costs of environmental policies can be split into those that consider only the transaction costs to the implementing agency, (the public cost), and those that also or explicitly analyse the transaction costs experienced by the private parties for whom the policy is developed to influence.

Studies that have looked at transaction costs to public parties include McCann and Easter (2000), who report that transaction costs to the public agency made up $38 \%$ of the total costs of the United States program of technical assistance for agriculture; Howitt (1994) who reports that transaction costs made up $8 \%$ of the water purchase cost for the Californian water bank; and Falconer et al. (2001) who found that public administration costs of Agri-Environmental Schemes (AESs) across Europe was 102\% of payments to landholders initially (1992/93) but declined over time to 18\% (1998/99). Falconer (2000), Falconer and Saunders (2002), Vatn et al. (2002), Rorstad et al. (2007), Kuperan et al. (2008) and Mettepenningen et al. (2009) are the only studies that include or explicitly analyse, the transaction costs of an environmental policy to private parties. Across those that included both public and private transaction costs, transaction costs ranged from $21 \%$ to $50 \%$ of total policy costs. Mettepenningen et al. (2009) explicitly look at private transaction costs of an AES and report that on average these are $15 \%$ of the total cost of the policy.

There are even fewer studies that include any discussion about what influences transaction costs to parties engaged in the environmental policy (see Falconer et al., 2001; Vatn et al., 2002; Rorstad et al., 2007; Nilsson, 2009; Mettepenningen and van Huylenbroeck, 2009). Understanding the influences of transaction costs informs both the ex ante selection of a policy and ex post policy refinement. Understanding the influences of transaction costs for environmental policy builds on research into typologies and measures of transaction costs (Thompson, 1999; McCann et al., 2005 and others) and is the focus of the remainder of the paper. 


\section{What influences transaction costs of environmental policy?}

The objective in this section is to set out what influences transaction costs to all parties engaged in an environmental policy and to generate an understanding of what causes these transaction costs to be high or low. We do this through an analysis of the organisational economics literature and results from empirical analyses.

\subsection{Organisational economics}

Organisational economics highlights the importance of transaction costs when considering the governance structure of a firm as a means of coordinating production related transactions compared to the neoclassical emphasis on the firm as a production unit (Williamson, 1981). Transaction cost minimisation was used to explain how a firm made decisions on the optimal coordination of production units (Coase, 1960; Williamson, 1998). The governance structure is theorised to influence the level and distribution of the transaction costs in coordinating production activities (Falconer, 2002). Organisational economics uses transaction cost economics in normative applications to identify the 'best' governance structure. That is, the 'best' governance structure for engaging in contracts is the one that minimises the transaction costs of creating and enforcing contracts. This is what Williamson $(1975,1981,1985,1999)$ refers to as discriminating alignment. The transaction costs of contracting emerge due to the characteristics of the transaction and the nature/behaviour of transactors (Williamson, 1996, 1998).

\subsubsection{The characteristics of the transaction as an influence of transaction} costs

Transaction characteristics that influence transaction costs are: asset specificity; timing/frequency or duration of the transaction; and uncertainty about the transaction (Williamson, 1998).

3.1.1.1. Asset specificity. Asset specificity is "specialised investment that cannot be redeployed to alternative uses or by alternative users without a loss in productive value" (Williamson, 1996:377). Asset specificity results in non-standard contracting and therefore transaction costs in exchange (Williamson, 1981). Asset specificity can be related to the site of production (where the asset is located affects the value of the transaction), be physically specific (specific inputs or actions are required to deliver transaction value) or be related to the labour (the specialised knowledge of the labour affects the transaction value) (Williamson, 1981). All three types of asset specificity exist for environmental goods.

The value of the transaction in an environmental good can be heavily dependent on the site (site specific). For example, if the objective of the transaction is to generate connected habitat, transactions of sites with habitat close to another protected area are likely to have higher habitat outcomes compared with a site situated further away from another protected area. This is discussed in the landscape ecology literature (see Hanski, 1994, 1999). Site specificity generates transaction costs due to the need to develop non-standard contracts and processes to achieve this connectivity and the investment in information to develop these non-standard contracts.

The value of the transaction in an environmental good may also be heavily dependent on the inputs (physically specific). In this case, the actions to generate a transaction in an environmental good are not the same for all sites and for all outcomes. For example, on-ground works to generate habitat for a bird species will not be the same on all properties. Further, inputs for bird habitat transactions will not necessarily be transferable for the conservation of other species (for example, to protect a legless lizard). The inputs to a transaction may make a transaction very specific to one outcome and not easily transferable to other transactions and other buyers. Once again, non- standard contracts are required to achieve the outcome which generates transaction costs higher than a standard contracting model.

Asset specificity also applies to the labour used in a transaction. This is primarily through labour knowledge. To conduct a transaction with an environmental good, a significant investment in knowledge about the good and how to transact it is made. This investment may be related to how to generate the good for a transaction (for example, where is a good investment site and what do you have to do on your land to generate the good to be transacted) or for how to conduct a transaction. For many environmental good transactions this investment in knowledge is not transferable (non-standard) to other transactions nor is knowledge gained in other transactions transferable to this transaction. This is because transactions in other environmental goods may need a different suite of knowledge about the product (for example, how to generate water quality outcomes will require different knowledge to habitat outcomes) or about the market (transactions through a competitive tender requires a different knowledge set to offset market transactions).

Asset specificity affects the transaction costs for both the public and the private parties to a transaction in an environmental good via activities such as information collection, implementation and contracting, support and administration and monitoring (see Table 1). Rorsted et al. (2007) suggests that asset specificity will influence transaction costs primarily through information collection. Barzel (1982) demonstrates how the transferability of knowledge affects transaction costs. That is, the more transferable experience a buyer has with a good the reduced need for rigorous measurement and the lower the transaction costs of purchase.

It is likely that the degree to which asset specificity affects the transaction costs of parties to an environmental policy is also dependent on the actions of other parties. For example, if the policy administrator invests in information collection and analysis and distributes this information freely to private parties who are engaged with the policy, the up-front and ongoing information collection and analysis costs of the private parties may be reduced at the expense of the public agency. Transaction costs may shift to the public policy administrator if asset specificity results in the policy administrator taking an ongoing role in policy interpretation for private parties and/or information dissemination tasks to assist private parties engage with the policy (Falconer, 2002). Interaction of actions and transaction costs is not analysed extensively in the literature.

3.1.1.2. Frequency/timing of the transaction. Organisational economics highlights that the number or frequency of the transactions also affects the transaction costs. This is because many transactions are recurring, particularly when the good being transacted is asset specific (Williamson, 1981, 1985, 1996, 1998; Buitelaar, 2007) which is the case for many environmental goods (Falconer, 2002). Organisational economics suggests that when transactions between the same parties are recurring, transaction costs across all transactions can be reduced by designing a suitable contract (i.e so each transaction does not need a new contract), this is particularly the case for large transactions of a recurring nature (Williamson, 1981). More frequent or repeated transactions between the same parties supported by a suitable contract can reduce the marginal transaction costs due to reduced efforts required in information collection and search costs for each individual transaction (Mettepenningen and van Huylenbroeck, 2009; Rorstad et al., 2007). Nilsson (2009) considered a learning effect responsible for reduced marginal transaction cost in repeat transactions over time.

3.1.1.3. Uncertainty surrounding the transaction. Mettepenningen and van Huylenbroeck (2009) distil Williamson's (1985) discussion of uncertainty to three components. The first is uncertainty of the future state of nature-how do you know that an agreed set of actions will result in the environmental outcome that you are aiming to provide or 
have contracted to provide. The second layer of uncertainty relates to what a party may be contracted to do. This level of uncertainty primarily relates to a lack of clarity of actions and procedures in a contract. The final level of uncertainty is related to the behaviour of the contracted parties. That is, how do you know that parties in the contract will honour the contract? This relates to behavioural uncertainty discussed in the next section of the paper with origins from Hayek (1945) and Williamson (1975). Mettepenningen and van Huylenbroeck (2009) limit their discussion to private parties; however policy administrators will also experience uncertainty over the state of nature and behaviour of contracted parties. Uncertainty influences transaction costs particularly when the transactions are asset specific. Transaction costs are likely to occur through reduced trades or activities employed to overcome uncertainty and generate trades (Williamson, 1985).

Uncertainty contributes to transaction costs through collection of information about the best environmental actions given the uncertainty of the outcome, and in clarifying and negotiating contracts. The impact of uncertainty on transaction costs experienced in policy instrument selection and design as well as policy monitoring is extensively covered in the non point source water pollution literature (Young and Karkoski, 2000; Brady, 2003; Goulder and Parry, 2008; Dowd et al., 2008). Ducos et al. (2009) note that for farmers participating in European AESs, uncertainty can generate high information collection transaction costs but which can be reduced through membership of a farmer organisation or engagement with extension agents. Transaction costs are lower to private parties when there is a specialist in information collection and provision (Stavins, 1995). Membership of a farmer organisation may also generate economies of scale for learning.

Uncertainty will also affect the transaction costs incurred in monitoring and enforcing activities of all parties. The degree of uncertainty is affected by how observable the desired actions or outcomes are (for the administrator) and how costly it is for a policy participant to demonstrate success. For example, removing and planting trees are highly observable and demonstrable actions. Other environmental actions have long time lags between the action and the outcome (diffuse source water quality improvement, for example) and are more costly to observe and demonstrate and thereby are more costly to monitor and enforce (Falconer, 2002). Vatn (2001) suggests that the transaction costs associated with low observability can be managed through the development of measures to be used as surrogates for the action or outcome which is difficult to observe. Vatn warns that the development of these surrogates is not free from transaction costs. The benefit of surrogate development needs to be weighed against the cost of developing these.

\subsubsection{The nature of transactors as an influence to transaction costs}

According to organisational economics, there are two characteristics of transactors that influence transaction costs. These are bounded rationality of transactors and the incentive for transactors to be opportunistic.

3.1.2.1. Bounded rationality. Bounded rationality acknowledges that people are rational but with limits to their ability to foresee all contingencies. That is, "boundedly rational agents experience limits in formulating and solving complex problems and in processing (receiving, storing, retrieving, and transmitting) information" (Simon, 1957). Bounded rationality means that there will be time and adjustment costs as transactors collect and analyse information before, during and after transaction decisions are made. Bounded rationality means that there will also be limits to a transactor's ability to identify 'efficient' transactions. The transaction cost effect of boundedly rational transactors is magnified when the transactions or the good being transacted is complex such as the case with highly asset specific goods.
Ducos et al. (2009) highlight that the education and the past experience of all parties reduce bounded rationality and associated information related transaction costs. Others, (Libecap, 1989; Challen, 2000) discuss the extent to which education and experience affects bounded rationality and transaction costs in terms of path dependency. Path dependence is a property of contingent, non reversible, dynamic processes, including a wide array of processes that can properly be described as evolutionary (David, 2007). If past actions have resulted in parties with knowledge and experience relevant to the policy or high social capital (i.e. parties trust one another and have bridging and bonding social networks) associated with the objective, it is likely that the transaction costs to all parties of the policy will be lower (Black and Lynch, 2005; Hatfield-Dodds and Pearson, 2005). Falconer et al. (2001) and Falconer (2002) note that past policy experience will initially reduce information collection costs and then reduce monitoring and enforcement costs throughout the life of the policy.

\subsubsection{Opportunism. Opportunism is described by Williamson (1981)} to be when decisions are made with self interest and guile. Opportunism may result in market participants providing false information or withholding important market information from other market participants (Falconer, 2002). When contracted actions are not easily observable and there is high uncertainty about actions and outcomes as these relate to the good, there is potential for opportunism by transactors.

One way to overcome opportunism is to form more complete contracts. However, more complete contracts are costly to develop, incurring transaction costs through the information collection requirements and through the time and other resources that these contracts consume to negotiate and complete. If complete contracts cannot be formed, increased monitoring of actions over time may be the compensating measure. Transaction costs are then incurred primarily by the contracting parties due to the time and effort invested in developing, contracting for and conducting monitoring and enforcement. The public policy administrator will also incur increased monitoring transaction costs to overcome opportunism through increased time and effort spent assisting in the forming of monitoring programs (such as certifying them), auditing monitoring programs and pursuing required enforcement processes.

\subsection{Other influences of transaction costs}

Organisational economics' normative use of transaction cost economics does not result in a complete understanding of transaction cost influences for an environmental policy (McCann et al., 2005). Current institutional environment and arrangements and the choice of policy relative to these and a number of additional transactor characteristics also influence transaction costs. These are discussed in this section.

\subsubsection{Current institutions}

North (1990), Vatn and Bromley (1994), McCann and Easter (1999, 2000) and Challen (2000) identify the influence that the current institutional environment, such as current property right arrangements, and the institutional arrangements, such as governance, have on the transaction costs of a new policy. North (1990) explicitly refers to these policy creation costs as transformation costs and notes that because history matters it is desirable for transformation costs to be included in any complete transaction cost evaluation.

The current institutional environment can create or reduce transaction costs of a new policy. If the environmental policy is consistent with the current institutional environment then harnessing current norms to support future policy operation, information dissemination, monitoring and enforcement may reduce the public 
transaction costs. This reduction is likely to occur due to reduced information collection, legislative (policy enactment) and administrative activities. Aligning the policy with existing institutional arrangements may also influence the information collection and learning related transaction costs borne by private parties. Challen (2000) highlights that past policies which privatised rights can create very high transaction costs for a new policy if this policy seeks to change these rights. Policy makers must be constantly considering future policies and future transaction costs as they develop current policies.

The institutional environment can also influence the type of policies that can be considered for an environmental good. For example, each level of government has defined limits to its powers which influence the policy options available or practicable. The current institutional environment can also limit the environmental policies that can be applied by non-government entities or independent government agencies such as regional management boards.

Mettepenningen and van Huylenbroeck (2009) note that transaction costs of private parties will also be affected by the level of centralisation of the governance structure. They suggest that the more decentralised a policy is, the lower the private transaction costs due to a reduction in paper work. Referring to the European AES, Mettepenningen and van Huylenbroeck (2009) also note that decentralisation can result in greater accuracy of payments to outcomes and therefore also a better environmental outcome. Falconer and Whitby (1999) discuss the potential for private party cooperatives and collaborations to reduce the private transaction costs in AES type schemes.

\subsubsection{Additional characteristics of the transactors}

Organisational economics only includes bounded rationality and opportunism as transactor characteristics that influence transaction costs. Morrison et al. (2008), Ducos et al. (2009), Mettepenningen and van Huylenbroeck (2009) and Morrison (2009) highlight three additional influences to transactor generated transaction costs: the trust between parties; having a common understanding or ideology between parties; and social connectedness.

Mettepenningen and van Huylenbroeck (2009) note that a trusting relationship between the public and private parties to an environmental policy 'transaction' reduces transaction costs in the processes that lead up to the establishment of a contract as well as in ongoing policy administration. This finding is supported by others including Ducos et al. (2009), Morrison et al. (2008) and Ducos and Dupraz (2006).

Mettepenningen and van Huylenbroeck (2009) suggest that a common ideology across parties reduces the transaction costs of interaction. This may be the case for the public party because there is a reduced need for public control (North 1997) and reduced need for the development and enforcement of complete contracts. Mettepenningen and van Huylenbroeck (2009) highlight that this could also be the case for private parties who may be more inclined to agree with the terms of the contract thereby reducing search and negotiation costs. Ducos et al. (2009) use farmer non-financial utility generated from the environment as a way to measure the common ideology between parties for AESs.

Morrison et al. (2008) highlight that participation in voluntary policies is influenced by private party transaction costs which are affected by the scheme design and the characteristics of the transactors such as social connectedness. Social connectedness refers to the connection of a party with other individuals and groups. Social connectedness can reduce the information collection costs of the private parties as they seek to learn about, adopt and adapt to a new policy. Harnessing social connectedness can also reduce the transaction costs of the policy administrator as adopters 'market' a policy to other potential transactors and these potential transactors enter the policy with a higher degree of initial trust in the policy (Morrison, 2009). ${ }^{6}$

Oates (1986), Libecap (1989), Williamson (1985, 1998), Milgrom and Roberts (1992), Bromley (1991) and Falconer et al. (2001) all discuss transactor characteristics such as: the number of participants in an environmental policy (cumulative and new entries each year); and the geographical characteristics of the transactors, as influential to the transaction costs borne by the administrator of the policy. The number of new participants impacts on the information dissemination costs to the public parties. The location of participants, new or continuing, relative to the location of the policy administrator influences the transaction costs experienced in policy implementation and monitoring. The number of new management options and private party knowledge about implementing these management options are noted by Falconer et al. (2001) to be transactor characteristics that influence transaction costs to private parties. Ducos et al. (2009) refer to these costs as technology costs. Transaction costs of a new technology will be experienced by private parties through information collection activities and through investment in different monitoring infrastructure and techniques. Public parties may also incur transaction costs from a changed technology as they collect information about the change and invest in new information and technology to conduct monitoring and enforcement.

\section{Conclusion}

Studies that report the extent of transaction costs to all parties in the creation and use of environmental policy instruments are limited but increasing. Those that exist demonstrate that transaction costs can be a large component of the total policy cost. Substantial effort has been made to inform transaction cost analysis and develop methods to increase the ability of the economics profession to measure transaction costs and by doing this, to better include transaction costs in policy instrument ex ante choice and ex post evaluation.

The importance of measuring transaction costs to better select, understand and refine policy is supported in this paper. However, in addition to generating an understanding of the magnitude of transaction costs, an understanding of the influences of transaction costs should also be improved if ex ante policy selection and ex post policy evaluation is to achieve efficiency objectives. The literature identifies three key influences of transaction costs in the creation and use of an environmental policy. These are: the characteristics of the transactions to take place; the nature of the transactors; and the current institutional environment and arrangements. ${ }^{7}$ A summary of these influences and their sub components is illustrated in Fig. 1. These affect the transaction costs to public and private parties due to their influence on activities such as information collection, policy enactment, administration, contracting, monitoring and enforcement.

The analysis of the influences of transaction costs leads to a number of conclusions. First, the significance of an influence to transaction costs varies between public and private parties and is affected by the actions and interactions between these two parties. For example, the biophysical characteristics of the environmental good and the nature of the transactors both have a bearing on the information collection transaction costs of both parties. However actions by one party, such as information collection and dissemination can significantly reduce the extent that these affect transaction costs for other parties.

\footnotetext{
${ }^{6}$ The opposite is also true which could significantly increase public transaction costs.

7 This is consistent with the broader literature on environmental policy selection and design. That is, an environmental policy should be selected and designed according to the ecological objectives and with an understanding of the social characteristics of the stakeholders and broader institutions (Young et al., 1996; Stoneham et al., 2000; Whitten et al., 2002; OECD, 2004; Pannell, 2008).
} 


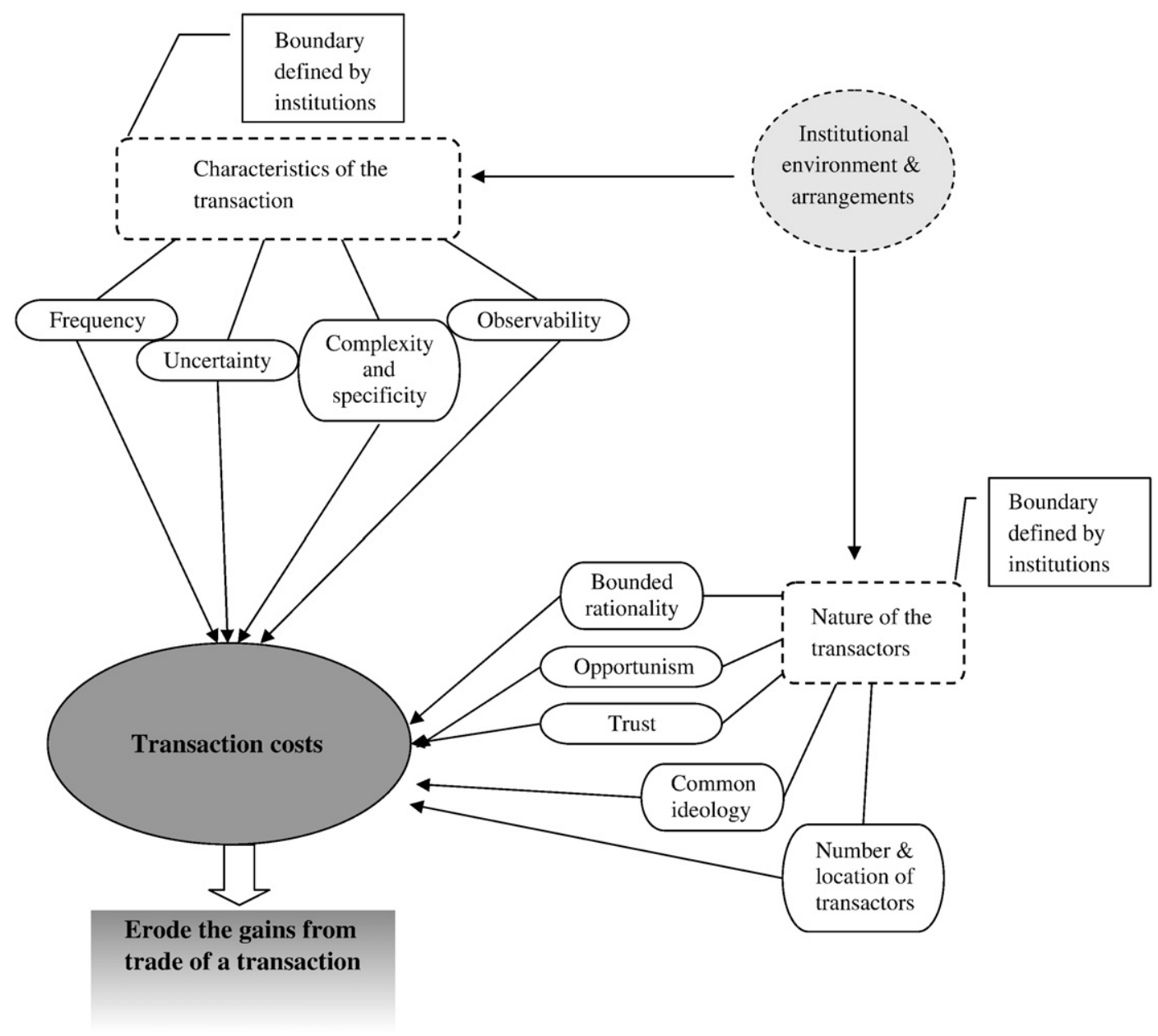

Fig. 1. Influences of transaction costs and impact on gains from trade.

Second, how transaction costs are experienced varies across time. For example, transaction costs experienced in activities such as information collection and information provision in initial policy stages may reduce the policy transaction costs experienced in ongoing policy operation in the future. These findings support those of Falconer et al. (2001), McCann et al. (2005), and Kuperan et al. (2008) with respect to transaction cost measurement. That is, the costs to all parties need to be analysed throughout the life of the policy to generate an accurate reflection of the total quantity and distribution of transaction costs.

Finally, the significance of a transaction cost influence depends on the policy instrument. For example, the influences of administration and support transaction costs for a policy where the public is a purchaser of environmental goods in a competitive tender will be different to a policy where the public sets up a framework where private transactors can trade environmental goods. The influences of transaction costs will be different again when comparing market based policy instruments with regulatory policy instruments. Policy instrument selection would benefit from a better understanding of measures and influences of transaction costs of different policies and across different parties.

The review of the literature revealed a number of weaknesses in understanding transaction costs of environmental policy. Not only is there a limited literature on the influences of transaction costs of environmental policy, there are also very few analyses of the extent of transaction costs of policies to both public and private parties. Measuring transaction costs to private parties is a high (transaction) cost exercise in itself, however without this information a complete understanding of the net benefit (or otherwise) of a policy cannot be made. Furthermore, questions surrounding the burden of transaction costs and the actions that shift the burden between parties are not currently analysed. This conclusion is particularly important given that there are tradeoffs to the private party of reducing public transaction costs and vice versa. Finally, most quantitative studies of transaction cost measures and influences have been conducted on programs that have voluntary involvement from private parties and with only one government 'buyer' of environmental goods. To completely understand environmental policy transaction cost measures and the influences behind these, a transaction cost analysis across the suite of available and potential policy instruments is desirable.

\section{Acknowledgements}

This paper was written with generous support from the Australian Government Marine and Tropical Science Research Facility and the CSIRO Water for a Healthy Country Flagship. Earlier versions of this paper benefited from input from Dr Leonie Pearson, Dr Graeme Marshall, Dr Edwin Buitelaar and two anonymous reviewers. Errors and omissions remain the responsibility of the authors.

\section{References}

Allen, D., 1991. What are transaction costs? Res. Law Econ. 14, 1-18.

Barzel, Y., 1982. Measurement cost and the organization of markets. J. Law Econ. XXV. Barzel, Y., 1985. Transaction costs: are they just costs? J. Inst. Theor. Econ. 141 (1), 4-16. Barzel, Y., 1997. Economic Analysis of Property Rights. Cambridge University Press, Cambridge. 
Black, S., Lynch, L., 2005. Measuring Organizational Capital in the New Economy: IZA Discussion Paper Series 1524.

Brady, M., 2003. The relative cost-efficiency of arable nitrogen management in Sweden. Ecol. Econ. 47, 53-70.

Bromley, D., 1989. Economic Interests and Institutions: the Conceptual Foundations of Public Policy. Gower, Oxford.

Bromley, D., 1991. Environment and Economy. Blackwell, Oxford.

Buitelaar, E., 2007. The Cost of Land Use Decisions: Applying Transaction Cost Economics to Planning and Development. Blackwell Publishing, Oxford, UK.

Challen, R., 2000. Institutions, transaction costs and environmental policy. Institutional reform for water resources. Edward Elgar publishing.

Cheung, S., 1969. Transaction costs, risk aversion and the choice of contractual arrangements. J. Law Econ. 12 (1), 23-42.

Coase, R., 1960. The problem of social cost. J. Law Econ. 3, 1-44.

Colby, B., 1990. Transaction costs and efficiency in western water allocation. Am. J. Agric. Econ. 72, 1184-1192.

Common, J.R., 1968. Legal foundations of capitalism. University of Wisconsin Press, Madison.

Dahlman, C., 1979. The problem of externality. J. Law Econ. 11, 141-162.

David, P.A., 2007. Path dependence, its critics and the quest for 'historical economics'. In: Hodgson (Ed.), The evolution of economics institutions: A critical reader.

Demsetz, H., 1970. The private production of public goods. J. Law Econ. 13, 293-307.

Dowd, B.M., Press, D., Los Huertos, M., 2008. Agricultural non point source water pollution policy: the case of California's Central Coast. Agric. Ecosyst. Environ. 128, $151-161$.

Ducos, G., Dupraz, P., 2006. Private provision of environmental services and transaction costs: agro-environmental contracts in France. Proceedings of the Environmental and Resource Economists 3rd World Congress, 3rd-7th July, 2006, Kyoto, Japan.

Ducos, G., Dupraz, P., Bonnieux, F., 2009. Agri-environment contract adoption under fixed and variable compliance costs. J. Environ. Plan. Manage. 52 (5), 669-687.

Falconer, K., 2000. Farm level constraints on Agri-environmental scheme participation: transactional perspective. J. Rural Stud. 16 (3), 379-394.

Falconer, K., 2002. Developing a co operative approach to Agri-environmental policies: a transaction cost perspective on farmer participation in voluntary schemes. In: Hoegendaan (Ed.), Environmental co-operation and institutional change. Theories and Policies for European Agriculture. Edward Elgar.

Falconer, K., Saunders, C., 2002. Transaction costs for SSSIs and policy design. Land Use Policy 19 (2), 157-166.

Falconer, K., Whitby, M., 1999. Transactions and administrative costs in countryside stewardship policies: An investigation for eight European member states. Research Report. University of Newcastle, School of Agriculture, Food and Rural Development.

Falconer, K., Dupraz, P., Whitby, M., 2001. An investigation of policy administrative costs using panel data for the English environmentally sensitive areas. J. Agric. Econ. 52 (1), 83-103.

Furubotn, E., Richter, R., 2000. Institutions and Economic Theory; the Contribution of the New Institutional Economics. University of Michigan Press, USA.

Goulder, L.H., Parry, W.H., 2008. Instrument choice in environmental policy. Rev. Environ. Econ. Policy 2, 152-174.

Grafton, R., Adamowicz, W., Dupont, D., Nelson, H., Hill, R., Renzetti, S., 2004. The Economics of the Environment and Natural Resources. Blackwell Publishing, USA.

Hanski, I., 1994. A practical model of metapopulation dynamics. J. Anim. Ecol. 63, 151-162.

Hanski, I., 1999. Habitat connectivity, habitat continuity, and metapopulations in dynamic landscapes. Oikos 87, 209-219.

Hatfield-Dodds, S., Pearson, L., 2005. The role of social capital in sustainable development assessment frameworks. Int. J. Environ., Workplace Employ. 1 (3/4), 383-399.

Hayek, F., 1945. The use of knowledge in society. Am. Econ. Rev. (35), 519-530.

Howitt, R., 1994. Empirical analysis of water market institutions: the 1991 Californian water market. Econ. Energy Environ. 13.

Kasper, W., 1998. Property Rights and Competition. The Centre for Independent Studies, Canberra.

Kuperan, K., Abdullah, N., Pomeroy, R., Genio, E., Salamanca, A., 2008. Measuring transaction costs of fisheries co-management. Coast. Manage. 36 (3), 225-240.

Lai, L., 1997. Chapters. Diamond and Massam: Progress in Planning, vol. 48, pp. 161-246.

Libecap, G., 1989. Contracting for Property Rights. Cambridge University Press.

Matthews, R., 1986. The economics of institutions and the sources of growth. Econ. J. 96, 903-918.

McCann, L., Easter, K., 1999. Evaluating transaction costs of non-point source pollution policies. Land Econ. 75 (3), 402-414.

McCann, L., Easter, K., 2000. Estimates of public sector transaction costs in NRCS programs. Agric. Appl. Econ. 32 (3), 555-563.

McCann, L., Colby, B., Easter, K., Kasterine, A., Kuperan, K., 2005. Transaction cost measurement for evaluating environmental policies. Ecol. Econ. 52, 527-542.

Mettepenningen, E., van Huylenbroeck, G., 2009. Factors influencing private transaction costs related to Agri-environmental Schemes in Europe. In: Bruwer, F., van der Heide, M. (Eds.), Multifunctional Rural Land Management: Economics and Policies.

Mettepenningen, E., Verspecht, A., van Huylenbroeck, G., 2009. Measuring private transaction costs of European agri environmental schemes. J. Environ. Plan. Manage. 52 (5), 649-667.

Milgrom, P., Roberts, J., 1992. Organisation and Efficiency. Economics, Organisation and Management. Prentice Hall, Englewood Cliffs, NJ.

Morrison, M., 2009. Encouraging the adoption of decision support systems by irrigators. Rural Soc. 19 (1), 17-31.
Morrison, M., Durante, J., Greig, J. \& Ward, J., 2008. Encouraging Participation in Market Based Instruments and Incentive Programs. Final Report prepared for Land and Water Australia.

Murtough, G., Aretino, B., Matysek, A., 2002. Creating markets for ecosystem services. Productivity Commission Staff Research Paper. AusInfo, Canberra.

Nilsson, F., 2009. Transaction costs and agri-environmental policy measures. Are preferences influencing policy implementation? J. Environ. Plan. Manage 52 (6) 757-775.

Nilsson, M., Sundqvist, T., 2007. Using the market at a cost: how the introduction of green certificates in Sweden led to market inefficiencies. Utilities Policy 15, 49-59.

North, D., 1990. Institutions, Institutional change and economic performance. Cambridge University Press.

North, D., 1997. Transaction costs through time. In: Menard, C. (Ed.), Transaction Cost Economics: Recent Developments. Edward Elgar Publishing, Cheltenham, UK, pp. 149-161.

Oates, W., 1986. Markets and externalities-comment 1. In: Bromley, D. (Ed.), Natural Resource Economics: Policy Problems and Contemporary Analysis. Kluwer Nijhoff Publishers, Dordrecht, Netherlands.

OECD, 2001. Multi functionality: Towards an Analytical Framework. OECD, Paris.

OECD, 2004. Handbook of Market Creation for Biodiversity: Issues in Implementation, Paris, France.

Ofei Mensah, A., 2008. Transaction costs analysis of alternative greenhouse gas policy instruments in the Australian transport energy sector. PhD Thesis, Australian National University.

Ostrom, E., 1990. Governing the Commons: the Evolution of Institutions for Collective Action. Cambridge University Press, Cambridge.

Ostrom, V., Ostrom, E., 1999. Public goods and public choices. In: McGinnis, M. (Ed.) Polycentricity and Local Public Economics: Readings from the Workshop in Political Theory and Policy Analysis. University of Michigan.

Pannell, D.J., 2008. Public benefits, private benefits, and policy mechanism choice for land-use change for environmental benefits. Land Econ. 84 (2), 225-240.

Rorsted, P., Vatn, A., Kvakkestad, V., 2007. Why do transaction costs of agricultural policies vary? Agric. Econ. 36, 1-11.

Schalger, E., Ostrom, E., 1992. Property-rights regimes and natural resources: a conceptual analysis. Land Econ. 68 (3), 249-262.

Simon, H., 1957. Administrative Behaviour. MacMillan, New York.

Stavins, R., 1995. Transaction costs and tradable permits. JEEM 29 (2), 133-148.

Stiglitz, J., 1986. Economics of the Public Sector, 2nd edition. W.W. Norton and Co, New York.

Stoneham, G., Crowe, M., Platt, S., Chaudhri, V., Soligo, J., Strappazzon, L., 2000. Mechanisms for Biodiversity Conservation on Private Land, Melbourne.

Thompson, D., 1999. Beyond benefit cost analysis: institutional transaction costs and regulation of water quality. Nat. Resour. J. 39, 518.

Vatn, A., 2001. Transaction costs and multifunctionality. Special Contribution to Session 5 OECD Workshop on multifunctionality.

Vatn, A., Bromley, D., 1994. Choices without prices without apologies. J. Environ. Econ. Manage. 26 (2), 129-148.

Vatn, A., Kvakkestad, V., Rorsted, P., 2002. Policies for multifunctional agriculture, the trade off between transaction costs and precision. Report number 23. Agricultural University of Norway, Department of Economics and Social Sciences.

Weimer, D.L., Vining, A.R., 1992. Policy Analysis Concepts and Practice. Pearson Prentice Hall, New Jersey.

Whitten, S., Bennett, J., 2005. Managing Wetlands for Private and Social Good. Edward Elgar, Cheltenham.

Whitten, S.M., Bennett, J.W., Handley, M., Moss, W., Phillips, B., 2002. Conserving freshwater ecosystems: current and potential incentive measures for private landholders. Main Stream Environmental Consulting for Department of Environment.

Williamson, O., 1973. Markets and hierarchies: some elementary considerations. Am. Econ. Rev. 63, 316-325.

Williamson, O.E., 1975. Markets and Hierarchies: Analysis and Antitrust Implications. Free Press, New York

Williamson, O.E., 1981. The economics of organization: the transaction cost approach Am. J. Sociol. 87 (3), 548-577.

Williamson, O.E., 1985. The Economic Institutions of Capitalism: Firms, Markets and Relational Contracting. Free Pres, New York.

Williamson, O.E., 1990. Chester Barnard and the incipient science of organization. In: Williamson, O.E. (Ed.), Organization Theory: from Chester Barnard to the Present and Beyond. Oxford University Press, New York, pp. 172-206.

Williamson, O.E., 1996. The Mechanisms of Governance. Oxford University Press, New York

Williamson, O.E., 1998. Transaction cost economics: how it works: where it is headed. De Economist 146, 23-58.

Williamson, O.E., 1999. Public and private bureaucracies: a transaction costs economics perspective. J. Law Econ. Organ. 15, 306-342.

Wills, I., 1997. Economics and the Environment; a Signalling and Incentives Approach. Allen and Unwin, St. Leonards.

Young, T.F., Karkoski, J., 2000. Green evolution: are economic incentives the next step in non point source pollution control? Water Policy 2, 151-173.

Young, M., Gunningham, N., Elix, J., Lambert, J., Howard, B., Grabosky, P., McCrone, E. 1996. Reimbursing the Future: an Evaluation of Motivational, Price Based, Property Right and Regulatory Incentives for the Conservation of Biodiversity. Canberra. 